\title{
KNOWLEDGE DESCRIPTION OF AMENORRHOEA LACTATION METHOD IN BREASTFEEDING MOTHERS IN THE SOKO SUB-DISTRICT HEALTH CENTER WORKING AREA IN TIKUNG DISTRICT LAMONGAN REGENCY
}

Research Report

\author{
Amellia Mardhika ${ }^{1}$ and Nur Sahid ${ }^{2}$ \\ 1,2DIII Nursing Study Program, Departement of Health, Faculty of Vocational Studies, Universitas \\ Airlangga
}

\section{A B STRACT}

Introduction: The Lactation Amenorrhoea Method or MAL is contraception that relies exclusively on breastfeeding or breast milk. From the initial survey the study found $40 \%$ of those who had not participated in Family Planning or Family Planning, and 60\% who had taken the Pill and Injections. The aim of the study was to describe the knowledge of MAL in nursing mothers in the Soko Sub-District Health Center Working Area, Tikung Subdistrict, Lamongan Regency.

Methods: This study used a descriptive design, with a population of 40 people and a sample of 30 people. The sampling used was Consecutive Sampling. Data collection with questionnaire sheets, after the data collected is done Editing, Coding, Tabulating, Scoring, percentage of data then analyzed descriptively data.

Results: Based on the results of research on knowledge of breastfeeding mothers about MAL, most (53.3\%) had insufficient knowledge, and a small percentage (6.7\%) had good knowledge. The conclusion of this study is that most nursing mothers have less knowledge about MAL.

Conclusion: The conclusion of this study is that most breastfeeding mothers have less knowledge about the Lactation Amenorrhoea Method or MAL.

\author{
ARTICLE INFO \\ Recived 18 December 2019 \\ Accepted 8 May 2020 \\ Online 29 May 2020 \\ *Correspondence: \\ Amellia Mardhika \\ *Email: \\ ameliamardhika@vokasi.unair.ac.id
}

Keywords:

Amenorrhoea Lactation Method (MAL), Knowledge,Nursing Mothers

\section{INTRODUCTION}

The new paradigm of the National Family Planning program has been changed its vision from realizing the Norm of a Happy Family of Prosperous Families or NKKBS into a vision to realize "Quality Families in 2015". A quality family is a family that is prosperous, healthy, advanced, independent, has an ideal number of children, forward-looking, responsible, harmonious, and devoted to the Almighty God. In this new paradigm of the Family Planning program, its mission strongly emphasizes the importance of efforts to respect reproductive rights, as an integral effort in improving family quality (Saifuddin \& et, 2006).

The National Family Planning Program has an important contribution in efforts to improve the quality of the population. The contribution of the National Family Planning program can be seen in the implementation of the Making Pregnancy Safer program. One of the key messages in the National Strategic Plan for Making Pregnancy Safer or MPS in Indonesia 2001-2010 is that every pregnancy must be the desired pregnancy (Saifuddin \& et, 2006).

To realize this key message, Family Planning is the most basic and primary preventive health care effort. To optimize the benefits of family planning for health, its services must be combined with available reproductive health services. Prevention of maternal death and illness is the main reason for the need for family planning services. There are many other reasons, such as freeing women from worrying about unwanted pregnancies, the occurrence of physical or psychological disorders due to unsafe abortion, and the demands of social development towards increasing the status of women in society. (Saifuddin \& et, 2006). 
The choice of contraception in nursing mothers is not a problem as long as medical personnel and patients pay attention to several physiological considerations. During pregnancy a physiological infertility occurs. Usually, the duration of pregnancy is proportional to the period of infertility that occurs, for example a premature pregnancy has a shorter period of infertility than a term pregnancy. In sufficient pregnancy, the month of ovulation returns 25 days sooner.

In mothers who give Mother's Milk or exclusive breastfeeding to their babies can delay from ovulation to 6 months. The baby's suction causes the release of prolactin which can suppress the ovulation process. When a baby is 6 months old, additional food must be given and breastfeeding tends to be reduced, so the possibility of ovulation increases. If you intend to use hormonal contraception, mothers and medical personnel must pay attention to some information in making the right decision. The hormones found in hormonal contraceptives can also be transferred to the mother's milk in large or small quantities, this depends on the hormones used. The effects of hormones on breast milk on infants are few but real. Possible effects of hormones on lactation, the quality and quantity of milk should also be a consideration. Finally, the risk of thromboembolic phenomena in contraceptives containing estrogen is a matter of concern, especially during the hypercoagulation period that occurs immediately after delivery. Ideally from the middle of pregnancy, a woman will know what family planning method she will use after giving birth (Ksuheimi, 2009).

A mother when giving exclusive breastfeeding to her baby, the advantage is infertility for 6 months. This phenomenon is an effective transitional method of family planning known as the Lactation Amenorrhoea Method or MAL. Transitional said because in the end the mother must choose another method if she wants to avoid pregnancy. MAL is best for mothers who are planning to breastfeed for 6 months or more. If the baby only gets food from breast milk or with a small amount of food additives, and the mother does not experience her first menstruation after giving birth, then the milk has a role $>98 \%$ in preventing pregnancy for 6 months after giving birth (Ksuheimi, 2009).

According to data from the Lamongan District Health Office, the number of babies in 2008 was 19,060 babies, the number of babies given exclusive breastfeeding reached 13,345 babies or $70.02 \%$. While mothers who use MAL contraception are not detected. Based on the results of a preliminary survey conducted in the Tikung Health Center Working Area, Tikung
Sub-district in February 2010 out of 10 breastfeeding mothers, 4 people or $40 \%$ had not yet participated in the $\mathrm{KB}$, and 6 people or $60 \%$ who had taken the Pill and Injections. So that from the data above, there is a problem that there are still nursing mothers who participate in Hormonal Family Planning in the Soko SubDistrict Health Center Working Area, Tikung District, Lamongan Regency.

Some of the factors that influence nursing mothers to follow MAL as one of the contraceptives include knowledge, education, work, age, interests, experience, socio-cultural, and information.

As the first factor is the knowledge of nursing mothers about MAL. Knowledge is the result of knowing, and this happens after people have sensed a certain object. Sensing occurs through the five human senses, namely the senses of vision, hearing, smell, taste and touch. Most human knowledge is obtained from the eyes and ears (Notoatmodjo, 2007).

The higher the knowledge of breastfeeding mothers about MAL, then it will receive MAL as one of the tools for interception. Conversely the lower the knowledge of breastfeeding mothers about MAL, they cannot accept MAL as a contraceptive.

Education is a form of intervention or effort that is planned to influence other people, individuals, groups, or communities so that they do what is expected by educational actors (Notoatmodjo, 2007).

The higher the education level of breastfeeding mothers, the easier it is for them to obtain and capture the information provided where the information is positive such as MAL as a contraceptive device. Likewise, conversely the lower the level of education of nursing mothers, it is difficult for them to capture information and ideas including about MAL as one of the important contraceptives for nursing mothers to prevent pregnancy.

Work is an activity carried out inside or outside the home. The work environment can make a person gain experience and knowledge both directly and indirectly (Mubarak \& et, 2007). Nursing mothers who do not have too much workload outside the home, the mother will have more time to breastfeed or use MAL. Conversely, if a breastfeeding mother is busy like working outside the home, chances are she will not have much time to breastfeed or use MAL.

With increasing age someone will change in physical and psychological aspects (mental). On the psychological or mental aspects of a person's level of thinking is more mature and mature (Mubarak \& et, 2007). A mother who has a more mature age will also be 
more mature way of thinking, the possibility of being able to use MAL as a contraceptive device. Conversely, a mother who has an easier age will also be less mature as well as her way of thinking, possibly unable to use MAL as a contraceptive device.

Interest as a tendency or high desire for something (Mubarak \& et, 2007). Nursing mothers who have a high interest in MAL from within themselves will easily achieve the goal of using MAL as a contraceptive device. Conversely, nursing mothers who have a low interest in MAL will inhibit the use of MAL as a contraceptive device.

Experience is a good teacher, experience is a source of knowledge or experience that is a way to obtain the truth of knowledge (Notoatmodjo, 2007). In multiparous mothers who have had experience with breastfeeding about MAL, it is possible to use MAL as a contraceptive device. On the other hand, in primiparous mothers who have never had breastfeeding experience about MAL, they may not be able to use MAL as a contraceptive device.

Socio-culture is as a development of compound words of culture, culture is the power of mind in the form of creativity, intention and taste (Noorkasiani, 2009). For urban communities with modern culture, they will be faster and get a lot of information about MAL, chances are they will not hesitate to the information that has been received, then use MAL as one of the contraceptives. On the other hand, for rural communities with traditional culture and lack of information about MAL, it is likely that they will doubt the information that has been received, then they do not want to use MAL as a contraceptive tool.

The ease of a person to obtain information can help speed up someone to gain new knowledge (Mubarak \& et, 2007). The higher the concern of health workers, especially those who act as educators in providing information and health education about MAL in nursing mothers, the nursing mothers will use MAL as one of the contraceptives. Conversely, if health workers do not provide information and health education about MAL in nursing mothers, then breastfeeding mothers will be hesitant in using MAL as a contraceptive device.
The positive and negative effects of MAL include the following: The positive impact is that it does not interfere with intercourse, there are no systemic side effects. So that the baby will get passive immunity or get protective antibodies through breast milk, the best source of nutritional intake and perfect for optimal baby growth and development, avoid exposure to contamination from water, other milk or formulas, or drinking tools used.

The mother can follow the MAL as a contraceptive, reduce postpartum bleeding, reduce the risk of anemia, increase the psychological risk of mother and baby. The negative effects are delay or suppression of ovulation. So that the mother who uses contraception can disrupt her menstrual cycle.

To increase the knowledge of breastfeeding mothers about MAL, as one method that can be used in berKB for breastfeeding mothers, the role of health workers, especially nurses as educators, is expected to help provide information by conducting counseling at the posyandu or when residents visit health services.

From several factors that can influence nursing mothers to use MAL as one of the contraceptives, the researchers only limit the knowledge factor.

The purpose of the research above is to find out the description of the knowledge of the Amenorrhoea Lactation Method in nursing mothers in the Soko Helper Health Center Working Area, Tikung Subdistrict, Lamongan Regency.

\section{MATERIALS AND METHODS}

This type of research is descriptive using the consecutive sampling method. The population of this study were all breastfeeding mothers in the working area of the Soko SubDistrict Health Center in Tikung Subdistrict, Lamongan Regency, in April-May 2010 as many as 50 people. While the sample is a portion of nursing mothers in the working area of the Soko Assistant Health Center, Tikung Subdistrict, Lamongan Regency, in April-May 2010 that fulfilled the inclusion criteria of 30 people.

In this study only using a single variable, namely knowledge of Amenorrhoea Lactation Method in nursing mothers and subvariables, namely: understanding MAL, how MAL works, MAL benefits, limitations of MAL, and things that need attention. 


\section{RESULTS}

Table 1 Distribution based on the age of respondents in the working area of Soko Sub-District Health Center Tikung District, Lamongan Regency in 2010

\begin{tabular}{cccc}
\hline No & Ages & Frequency & Precentage \\
\hline 1 & $\leq 20$ years & 3 & 10,0 \\
2 & $20-25$ years & 15 & 50,0 \\
3 & $26-30$ years & 2 & 6,7 \\
4 & $\geq 30$ years & 10 & 33,3 \\
\hline & & 30 & 100
\end{tabular}

Shows that half or some are aged $20-25$ years or $50 \%$ and a small percentage are aged $26-30$ years or $6.7 \%$

Table 2 Distribution based on respondent's education in the working area of Soko Sub-District Health Center Tikung District, Lamongan Regency in 2010

\begin{tabular}{cccc}
\hline No & Education & Frequency & Precentage \\
\hline 1 & Elementary School & 9 & 30,0 \\
2 & Junior High School & 14 & 46,7 \\
3 & Senior High School & 4 & 13,3 \\
4 & University & 3 & 10,0 \\
\hline & Total & 30 & 100
\end{tabular}

Shows that almost half or some have junior / MTs education or $46.7 \%$ and a small percentage have a PT / D3 / S1 education or $10 \%$.

Table 3 Distribution based on the work of respondents in the working area of the Soko Sub-District Health Center Tikung District, Lamongan Regency in 2010

\begin{tabular}{cccc}
\hline No & Jobs & Frequency & Precentage \\
\hline 1 & Job less / house wife & 20 & 66,7 \\
2 & Farmer & 5 & 16,7 \\
3 & Entrepreneur & 5 & 16,7 \\
4 & Civil Servant & 0 & 0 \\
\hline & Total & 30 & 100 \\
\hline
\end{tabular}

Shows that most do not work / housewives or $66.7 \%$, and a small number work as farmers or private / self-employed or $16.7 \%$.

Table 4 Distribution based on the work of respondents in the working area of the Soko Sub-District Health Center Tikung District, Lamongan Regency in 2010

\begin{tabular}{|c|c|c|c|}
\hline No & Total of Children & Frequency & Precentage \\
\hline 1 & 0-1 people & 3 & 15,0 \\
\hline 2 & 2-3 people & 9 & 45,0 \\
\hline 3 & $\geq 3$ people & 6 & 30,0 \\
\hline \multicolumn{2}{|c|}{ Total } & 30 & 100 \\
\hline
\end{tabular}

Shows that the majority of mother children are $0-1$ people or $60 \%$ and almost half or part of the number of mother children $2-3$ people or $40 \%$. 
Table 5 Distribution of knowledge of breastfeeding mothers about the amenorrhoea lactation method (MAL) in the working area of the Soko Assistant Health Center Tikung District, Lamongan Regency in 2010

\begin{tabular}{cccc}
\hline No & Category & Frequency & Precentage \\
\hline 1 & Less Knowledge & 16 & 53,3 \\
2 & Enough Knowledge & 12 & 40,0 \\
3 & Good Knowledge & 3 & 6,7 \\
\hline & Total & 30 & 100 \\
\hline
\end{tabular}

Shows that most have less knowledge or $53.3 \%$, and some have good knowledge or $6.7 \%$.

\section{DISCUSSION}

Based on table 5 shows that of all breastfeeding mothers in the Soko Sub-District Health Center Working Area in Tikung Subdistrict, Lamongan Regency in 2010 found that most of them possessed insufficient knowledge, and some had good knowledge about the Lactation Amenorrhoea Method or MAL.

This can be influenced by several factors, especially the background of age, education, employment, number of breastfeeding mothers. Impacts on several other factors such as interest, experience, socio-culture, and information on nursing mothers.

Age of breastfeeding mothers based on table 1 shows that half or some are aged 20-25 years and a small percentage are aged 26-30 years. With increasing age someone will change in physical and psychological aspects (mental). On the psychological or mental aspects of a person's level of thinking increasingly mature and mature (Wahid lqbal Mubarak, 2007). In mothers who have a more mature age, they will also be more mature way of thinking, can receive MAL as a contraceptive device. On the other hand, for mothers who have an easier age, they will also be less mature in their way of thinking, so it is more difficult to accept MAL as a contraceptive device.

The education of breastfeeding mothers based on table 2 shows that almost half or part of them are junior high school / MTs educated and a small proportion are educated PT / D3 / S1. Education is a form of intervention or effort that is planned to influence other people, individuals, groups or communities so that they do what is expected by the perpetrators of education (Soekidjo Notoatmodjo, 2007). The higher the education level of breastfeeding mothers, the easier it is for them to obtain and capture the information provided where the information is positive such as MAL as a contraceptive device. Likewise, on the contrary, the lower the education level of breastfeeding mothers, it is difficult for them to capture information and ideas including about MAL as one of the important contraceptives for nursing mothers to prevent pregnancy.

Knowledge is the result of knowing, and this happens after people have sensed a certain object. Sensing occurs through the five human senses, namely the senses of vision, hearing, smell, taste and touch. Most human knowledge is obtained from the eyes and ears (Soekidjo Notoatmodjo, 2007). The higher the knowledge of breastfeeding mothers about MAL, the MAL will be chosen as one of the tools for interception. Conversely the lower the knowledge of breastfeeding mothers about MAL, it will be difficult to choose MAL as one of the contraceptives.

The work of breastfeeding mothers based on table 3 shows that most do not work / housewives and a small number work as farmers or private / self-employed. Nursing mothers who live with daily activities or work will tend to ignore health conditions, so they do not get information and health education about MAL in nursing mothers. While nursing mothers who work outside the home can get new things and seek information and health education about MAL in nursing mothers. Where people who work outside the home can exchange experiences or knowledge with others. Experience or knowledge gained will be more varied so nursing mothers will feel confident that MAL as one of the important contraceptives for nursing mothers prevents pregnancy. In accordance with the opinion expressed by Wahit lqbal Mubarak (2007) that the work environment can make someone gain experience and knowledge both directly and indirectly.

Socio-culture is as a development of compound words of culture, culture is the power of mind in the form of creativity, intention and taste (Noorkasiani, 2009). For urban people with modern culture, they will be faster and get a lot of information about MAL, they will not hesitate about the information that has been received, then use MAL as a contraceptive 
device. On the other hand, for rural communities with traditional culture and lack of information about MAL, they will doubt the information that has been received, then do not want to use MAL as one of the contraceptives.

The ease of someone to obtain information can help speed up someone to gain new knowledge (Wahid lqbal Mubarak, 2007). The higher the concern of health workers, especially those who act as educators in providing information and health education about MAL in nursing mothers, the nursing mothers will use MAL as one of the contraceptives. Conversely, if health workers do not provide information and health education about MAL in nursing mothers, then nursing mothers will hesitate in using MAL as a contraceptive device.

The number of breastfeeding mothers based on table 4 shows that the majority of mothers have 0-1 children and almost half or part of the mother's children are 2-3 people. With the increasing number of children, it will be easier to interact and receive information from outside. Conversely, the fewer the number of children, the more difficult it will be to interact and receive information from outside.

Experience is a good teacher, experience is a source of knowledge or experience that is a way to obtain the truth of knowledge (Soekidjo Notoatmodjo, 2005). In multiparous mothers who have had experience with breastfeeding about MAL, it is possible to use MAL as a contraceptive device. On the other hand, in primiparous mothers who have never had breastfeeding experience about $M A L$, they may not be able to use MAL as a contraceptive device.

Interest as a tendency or high desire for something (Wahid lqbal Mubarak, 2007). Nursing mothers who have a high interest in MAL from within themselves will easily reach the goal by using MAL as one of the contraceptives. Conversely, nursing mothers who have a low interest in MAL will inhibit the use of MAL as a contraceptive device.

\section{CONCLUSION}

Based on the results of the study, in 30 breastfeeding mothers in the Soko Sub-District Health Center Working Area in Tikung Subdistrict, Lamongan Regency and a discussion about the knowledge of nursing mothers about the Lactation Amenorrhoea Method or MAL. The conclusion that can be taken from this study is that most breastfeeding mothers possess less knowledge about the Lactation Amenorrhoea Method or MAL.

\section{REFERENCES}

Arikunto, S. (2010). Prosedur Penelitian Suatu Pendekatan Praktik. Jakarta: Rineka Cipta.

Gibney, M. J., \& et al. (2009). Gizi Kesahatan Masyarakat. Jakarta: EGC.

Hidayat, A. A. (2011). Metode Penelitian Keperawatan dan Teknik Analisa Data. Jakarta: Salemba medika.

Mubarak, W. I., \& et al. (2007). Promosi Kesehatan: Sebuah Pengantar Proses Belajar Mengajar dalam Pendidikan Edisi 1. Yogyakarta: Graha IImu.

Noorkasiani. (2009). Sosiologi Keperawatan. Jakarta: EGC.

Notoatmodjo, S. (2007). Kesehatan Masyarakat IImu dan Seni. Jakarta: Rineka Cipta.

Nursalam. (2008). Konsep dan Penerapan Metodelogi Penelitian IImu Keperawatan Edisi 2. Jakarta: Salemba Medika.

Purwanti, H. S. (2009). Konsep Penerapan Asi Eksklusif: Buku Saku untuk Bidan. Jakarta: EGC.

Saifuddin, A. B., \& et al. (2006). Buku Panduan Praktis Pelayanan Kontrasepsi Edisi 2 Cetakan 2. Jakarta: Yayasan Bina Pustaka Sarwono Prawiroharjo.

Suryoprajogo, N. (2009). Keajaiban Menyusui. Jogjakarta: Keyword.

Varney, H. (2008). Buku Ajar Kebidanan Edisi 3 Volume 2. Jakarta: EGC.

Wiknjosastro, H. (2009). Ilmu Kebidanan. Jakarta: Yayasan Bina Pustaka. 